Јована Г. Тодоровић

Сара Ж. Матин

Универзитет у Новом Саду

Филозофски факултет

Студенткиње докторских студија

t.jovana.todorovic@gmail.com

sara.matin124@gmail.com
УДК: 821.163.41.09

DOI: 10.19090/ZJIK.2021.143-154

оригинални научни рад

\title{
РЕПРЕЗЕНТАЦИЈЕ РОДНОГ У ПЕСНИЧКОЈ ЗБИРЦИ МОЈА МАМА ЗНА ШТА СЕ ДЕШАВА У ГРАДОВИМА РАДМИЛЕ ПЕТРОВИһ
}

САЖЕТАК: У раду се истражује песничка збирка Моја мама зна шта се дешава у градовима младе песникиње Радмиле Петровић, односно начин на који се у њој обликује родно. Трећа збирка Радмиле Петровић нашла се у центру пажње српске читалачке публике почетком треће деценије 21 . века и у савремену поезију унела је извесне новине на тематско-мотивском плану. Битан одмак у односу на претходне збирке могуће је пронаћи у покретању питања пола и рода, а све то у контексту опозиције село-град. Појмови пола и рода у спрези су са односом према традицији, патријархату, моди, шминкању, али и политици. Као такви они функционишу као неки од основних појмова за разумевање песничког света који Радмила Петровић гради у овој збирци, те их је циљ научно осветлити и ударити темеље даљем књижевно-теоријском истраживању поезије значајних представника млађе генерације савремених песника.

Кључне речи: савремена поезија, лезбејство, мотив шминке, патријархат, фигура мајке

Почетак треће деценије 21. века на домаћој књижевној сцени обележила је појава неколико аутентичних женских песничких збирки. Као једно од најзначајнијих и најзапаженијих песничких остварења, истиче се трећа збирка поезије Радмиле Петровић, Моја мама зна шта се дешава у градовима, у издању издавачке куће PPM Enklava, примарно фокусиране на објављивање поезије млађе генерације савремених српских песника. Збирка Радмиле Петровић унела је у савремену поезију извесне новине на тематскомотивском плану. Песникиња је у њој начинила битан одмак у односу на своје две претходне збирке, Мирис земље (2015) и Целулозни рокенрол (2016), тематизујући питања пола и рода, а све то у контексту опозиције село-град, која чини окосницу песничког света Петровићеве. Појмови пола и рода, као основни имениоци којима можемо дефинисати сексуални 
идентитет лирског субјекта, у спрези су са односом према традицији, патријархату, моди, шминкању, али и политици.

\section{1. МАНИПУЛАЦИЈА РОДНИМ ОЗНАЧИТЕЉИМА}

Према теорији перформативности рода, о којој говори Џудит Батлер, родне одлике не претходе језику, већ је језик тај који их конструише и утврђује (Buttler 1990: 24-25). Занимљивим се у том смислу чини језик поезије Радмиле Петровић. Када год се лирски субјекат идентитетски одређује, или пак када покушава друге идентитетски да означи, долази до употребе полусложеница. Отуда је важно поставити питање како се тај избор одражава на значењском плану. Полусложеница има својства обе речи које је сачињавају, при чему сам полусложенички спој генерише ново заједничко значење. На пример, наилазимо на именичке полусложенице неологизме ${ }^{1}$ мушкарац-дама или шмекер-девојка. И у једном и у другом случају једна реч је полни означитељ (мушкарац, девојка), а друга је друштвени конструкт (дама, шмекер). Лирски субјекат репрезентује се увек као подељен између биолошког пола и улоге која му је приписана од стране породице и друштва. Отуда се јавља свест која у себи истовремено сабира феминино и маскулино, а кроз чију призму он посматра себе и друге људе, друштвене појаве, културне феномене, итд.

Тако је позиција шмекер-девојке позиција из које се ова поезија исписује. Лирски субјекат настоји да заузме позицију моћи, а она у овом случају омогућава слободно изражавање и критичко-субверзивни став. Такву позицију заузима манипулацијом особинама маскулиног и фемининог, узимајући и из једне и из друге сфере оно што даје легитимитет пробуђеном гласу. Стога је могуће говорити о две тенденције. Прва се односи на приписивање мушких атрибута сопству да би се на тај начин супротставило оном што се опажа као култивисана женскост, као и да би се, с обзиром на то да мушки принцип важи за активистички, стало у одбрану женске позиције у патријархалном друштву. Контрадикторна, али у својој суштини

\footnotetext{
${ }^{1}$ У случају споја мушкарац-дама, али и девојка-хајдучка трава, поставља се питање да ли се оне уопште могу одредити као полусложенице. Да би се нешто одредило као полусложенице, прва саставница мора бити индеклинабилна, а то овде није случај. Такође, у полусложеницама прва саставница одређује другу. Погледамо ли спојеве мушкарац-дама и девојка-хајдучка трава, јасно нам је да је ситуација обрнута друга саставница одређује прву. Управо због тога ови спојеви могу се схватити као врста неологизма.
} 
предвидљива, друга тенденција односи се на употребу женског језика, која је уско везана за фигуру мајке и матерински принцип.

Када је реч о првој тенденцији, она се посебно огледа у ономе што бисмо могли одредити као некултивисаност. Та некултивисаност најпре се одражава на нивоу лексике. Затим, могуће ју је пратити кроз изузетно присутан мотив шминке. Лирски субјекат се супротставља свему оном што није природно, истичући тиме сирову, необрађену женскост. Лексика која је најфреквентнија односи се на свет предметности села. Тако се често наилази на саму реч село, а потом на оруђе и алате (чекић, плуг, секира), машине (трактор, багер), домаће животиње (петао, крава, пилићи, прасићи) и поврће (грашак, лук, парадајз). Језик је, дакле, у највећој мери лишен уређености и тежи економичности. То је пре свега уочљиво у реткој употреби придева. Придеви се користе онда када су готово успутни или логични. На пример, ловачки жути пси. Међутим, када се описује нешто што је важно за интимни свет лирског субјекта, придеве поново замењују именице у полусложеницама. Примера ради, уместо израза снажна девојка, наилазимо на израз девојка хајдучка-трава. Како је и језик лишен улепшавања, тако постоји и негација шминке као козметичког ${ }^{2}$ средства. Супротно бодлеровској тврдњи да је шминка оспољавање човековог осећаја за лепо, она се посматра на немодеран начин, односно као сувишност и артифицијелност.

\section{2. ШМИНКА: ШМЕКЕР-ДЕВОЈКА И ДЕВОЈКЕ-ДЕВОЈКЕ}

Један од упечатљивих мотива који се јављају у збирци Моја мама зна шта се дешава у градовима јесте мотив шминке. Лирски субјекат, који је експлицитно изједначен са ауторком, спорадично уноси мотив шминке у песме, при чему је његова основна функција успостављање важне дистинкције између лирског субјекта као шмекер-девојке и осталих девојака, не-даме и дама. Мотиви шминке и моде јавили су се и у прве две песничке збирке Радмиле Петровић, у Мирису земље и Целулозном рокенролу, премда је тада њихова функција била друкчија. Није била толико везана за одређивање себе колико за одређивање социјалног контекста и једног типа девојака са којима се лирски субјекат сусреће. Већ у тој поезији можемо пронаћи став да је шминкање нешто што је вештачко. Артифицијелну

\footnotetext{
2 Реч козметика потиче од грчке речи kosmētikos, настале од речи kosmein и kosmos, које суштински имају значење реда, поретка, уређивања, тј. украшавања.
} 
природу шминкања најбоље ћемо видети на радикалном примеру вештачких трепавица које ће лирски субјекат назвати „пластичним“, али ће тај мотив употребити изузетно домишљато како би боље описала тежину капака у песми „У питању је нешто теже“, истовремено упутивши суптилну критику шминкању тинејџерки (Петровић 2015: 9). Мотив шминке само је део мотива дотеривања или моде, али важно је увидети да око Петровићеве увек примећује оно што је вештачко, те поред пластичних трепавица проналазимо и вештачко крзно и синтетичке чарапе.

Експлицитан став о шминкању песникиња ће изнети тек у трећој збирци. Успоставиће основну опозицију по којој је шминка нешто вештачко, а њено некоришћење нешто природно, која ће се даље трансформисати у то да је шминка симбол женствености и девојке-девојке, док је одсуство шминке карактеристика лирског субјекта као шмекер-девојке.

Негативна оцена шминке и схватање шминке као вида артифицијелности имају изузетно дугу традицију. Осврнемо ли се на прошлост, препознаћемо их у хришћанству, које се као православље, у српској средини показује се као конститутивни елемент патријархата. Свака измена природног изгледа човека, обличја које му је Бог дао, схвата се као непоштовање самог створитељског чина. Негативан став проналазимо и у исказима значајних филозофа, међу којима се посебно истичу Фридрих Ниче и Артур Шопенхауер, али и код одређених феминисткиња (нпр. код Уне Стенард и Симон де Бовоар) које шминку поимају као последицу спољашњих, махом мушких, друштвених притисака на жену (в. Negrin 2020).

Мотив шминке појављује се већ у песми „Девојка која не верује у митове“, која отвара читаву збирку. Девојка-лирски субјекат рођена је као не-мушко, као „опет женско“ биће којем пророчица није добро проценила пол, те за такве девојке говори да: „не користе маскару / него масат и француски кључ / возе трактор / цеде чварке / и једу кавурму“ (Petrović 2020: 7). Маскара, као елемент шминке, део је атрибуције женског, док је лирски субјекат не користи и више се идентификује с атрибуцијама и одликама карактеристичним за мушкарца.

Премда ће у песми „Играчке сте куповали за сина“ лирски субјекат признати да су некада постојали покушаји да буде „девојка сензуална / софистицирана / девојка-девојка“, у свим осталим песмама јасно ће се нагласити сопствена природа, која се противи шминки и негује изразито негативан однос према оним девојкама које се шминкају, што се у крајњој инстанци може схватити као манифестација нескривене мизогиније према 
одређеној групи припадница женског пола. Песма у којој видимо ту мизогинију јесте „Тај момак је спреман све да остави, само не цигарете“ у стиховима: „има добру грађу, лепа је / вероватно се буди нашминкана / али остариће“ (Petrović 2020 : 27). Мотив женског старења овде је употребљен са дозом цинизма, усмереног против идеала женске безвременске лепоте, управо оног идеала због кога су се шминки противиле и феминисткиње попут Уне Стенард и Симон де Бовоар.

У песми „Четири пољупца да спасемо свет“ лирски субјекат опева мушкарца коме би боље одговарала жена супротног типа него што је она. Основна дистинкција између лирског субјекта и друге жене проналази се у манирима и физичком изгледу. Лирски субјекат дефинисаће се тиме да није дама, те ће за себе рећи следеће: ,ја немам скупе хаљине / немам хаљине уопште / често грицнем живац испод нокта / држим лактове на столу“ (Petrović 2020: 22). Другој жени, дами, приписаће се „најлепше хаљине“ и „прикладан мејкап“, као и правилно умеће конзумирања дагњи, које су евидентно овде симбол буржоаског и градског елитизма, у које се она са својим васпитањем не уклапа. Но, у песми „Немам с ким да пљујем у лавабо наизменично пасту за зубе“, када наиђе на незаинтересованост мушкарца до ког јој је стало, лирски субјекат ће ипак ускликнути: „а ја сам ипак девојка / каква-таква / рођена девојка! / не претерано женствена“" (Petrović 2020: 32).

Поред тога што се налази у првој песми, мотив шминке своје место има и у последњој песми, „Само желим неког да расклопимо трактор мог оца у тишини“. Апострофирајући оца, о себи каже следеће: „а знаш каква ћу ја, тата, бити жена / јака као шифре на имејлу / нећу се шминкати, хранићу се здраво / на мом челу писаће органик“ (Petrović 2020: 62). С једне стране је, дакле, шмекер-девојка, коју одликују срчаност, снага и природност, а с друге стране су нашминкане девојке-девојке, које се као даме уклапају у стереотипну слику „слабијег пола“. Као посебно занимљива показује се реч органик. Премда се њоме истиче природност лирског субјекта, наравно, везана за порекло из сеоске средине, њен иронични призвук може се тумачити и као својеврсни дијалог са трендом присутним у савременом друштву, оспољеном у жељи не само за храном већ и за органском козметиком, тј. за шминком са етикетом органик.

Јасно је да је мотив шминке у поетичком систему Радмиле Петровић уско повезан са опозицијом природно-вештачко, која се у даљој инстанци уклапа у опозиције село-град, рурално-урбано, традиционално-модерно. Не 
само да је тематизација мотива шминке значајна за песнички опус Петровићеве већ се показује и као особен случај у српској поезији.

\section{3. АНГАЖОВАНОСТ ЛИРИКЕ: СУПРОТСТАВЉАҢЕ ПАТРИЈАРХАТУ И ЛЕЗБЕЈСТВО КАО ПОЛИТИЧКИ АКТ}

Идентификовање са особинама маскулиног огледа се у активистичком начелу одбране и борбе. Парадоксално, у овом случају то је глас лирског субјекта као оног ко стаје у одбрану жена и женских предака. У интервјуу са Дејаном Војводићем, Радмила Петровић поезију одрећује као место разрачунавања, али оно које не мора да садржи ангажоване усклике и крилатице. Отуда цени „ангажованост на тематски нижим нивоима“ (Vojvodić 2020). Након што је пронађен модус певања из позиције новоформиране улоге шмекер-девојке, који не ствара осећај угрожености, песникиња своју поезију доживљава као простор у ком слободно може да стане у одбрану и оних других, оних који немају апарат кроз који могу да испоље сопствено незадовољство. У истом интервјуу, Петровићева истиче: „Не можете се разрачунати како треба ако гледате само себе, морате то урадити и за оне пре вас који то нису могли/хтели/умели да ураде“(Vojvodić 2020). Овакав исказ поезију Радмиле Петровић директно смешта у сферу политике књижевности. Према Жаку Рансијеру, „политичка активност прекраја деобу чулног“, односно, „чини видљивим оно што је било невидљиво, омогућава онима који су били сматрани за бучне животиње да се чују као бића која говоре“ (Рансијер 2008: 8).

Тако песма „Шума, плуг, јагорчевина“ започиње стиховима: „осећам душе женских предака / које су настрадале од мушке руке“ (Petrović 2020: 29). Гласови настрадалих жена обраћају се лирском субјекту као неком ко сада има моћ да их освети - „говоре ми сеци их као пихтије!“ (Petrović 2020: 29). Међутим, присутно је аутопоетичко преиспитивање - у којој мери је уопште могуће бити песнички медијум, шта то повлашћено место не успева да предвиди? Отуда стихови: „снаго, не пристај да будеш нечија / изађите из мојих песама! / и ви сте хтеле само синове/ који су вам после разбијали главе“" (Petrović 2020: 30). Патријархат се, дакле, показује као нешто што је дубоко укорењено у друштву. У песми „Планина у пламену“ лирски субјекат у себи осећа трагове могућности да буде представник мушког поретка: „некад кроз мене проструји крв предака / оних што су убијали своје жене“ или „тата, у овој ћерки имаш помало сина / који се није родио“ (Petrović 
2020: 37). Услед захтева патријархата, константно долази до конструкције маскулиног. Песма „Говорили су ми да је Београд град у коме никог не смеш да погледаш у очи“ започиње стиховима: ,jа сам шмекер-девојка / имам перорез у џепу / и жице у брусхалтеру (Petrović 2020: 8). У другом стиху строфе требало би маркирати реч перорез. Једна од симболичких функција перореза јесте фалусоидна ${ }^{3}$. Превазилажење фалогоцентричног друштва остварује се усвајањем његових начела, с тим да се њима различито располаже. У песми „Моја лоза има дар да скрати линију живота“, перорез који се носи у џепу има функцију одбрамбеног средства, које лирског субјекта, као девојку, треба да сачува од наслеђене карме од стране мушких чланова породице, обележене насиљем и клетвама. Ова тематика у појединим песмама задобија и емоционалну димензију, као на пример у песми „Пре поласка у школу знала сам шта је одузимање“: „штета што није мушко / мислиле су стрине испод ока“ (Petrović 2020: 19). Завршни стихови сведоче о настојањима да се та очекивања превазиђу: „увек сам успевала / да све урадим како треба / а они ми никад нису опростили / што сам Радмила“ (Petrović 2020: 19). Међутим, не само да се песникиња супротставља мушком и патријархалном у оквиру породичног система и села већ то чини и на плану националног. То потврђује наслов песме „Српкиња сам, ал' ми Косово није у срцу, него ти“. Присутан је субверзиван став према свим великим наративима које патријархат обликује, односно учвршћује. Отуда се у тој песми национални симбол божура своди на домен личног трансформисањем у метафору женске интиме: „побогу човече, наспавајте се // у вези с косовским питањем / генерале, // божури цветају // у мојим гаћицама“ (Petrović 2020: 51).

Иако је одавно прошло време табуа када је у питању хомосексуалност, ово је, такође, тема коју поезија Радмиле Петровић поставља у домен чулног. Тематизација лезбејства присутна је у појединим

3 Суштински, свака врста ножа или бодежа има фалусоидне конотације. Но, занимљивим се чини сетити се романа Госпођа Даловеј Вирџиније Вулф, у коме се реч перорез појављује укупно десет пута. Перорез је повезан с ликом Питера Волша, који га непрестано има уз себе и поиграва се њиме. На пример, у сцени на Трафалгар скверу: „Ispravivši se i u potaji igrajući se svojim perorezom (подвукле J.Т. и С.M.), on pođe za tim uzbuđenjem, za tom ženom, koja kao da ga čak i leđima okrenuta obasipa nekom svetlošću i kao da ih ta svetlost vezuje, kao da je odabrala baš njega, kao da ravnodušna buka saobraćaja potajno šapuće njegovo ime, ne Piter, već njegovo intimno ime kojim je sebe nazivao u mislima. »Vas«, rekla je ona, samo »Vas«, izgovarajući to svojim belim rukavicama i ramenima“" (Vulf 1964: 46). 
песмама само у сугестији и назнакама, док је у неким врло експлицитно исказана. Песме су писане у исповедном тону и свака од њих је адресована неком члану породице: оцу, мајци, деди и тетки. Јасно је да постоји потреба да се оно што патријархално друштво сматра неприхватљивим, а што је присутно у интимном свету лирског субјекта, разреши кроз чин писања онима од којих се подсвесно увек тражи одобравање.

Однос патријархата према лезбејству тако је приметан већ и у самом наслову песме „Тетка каже то је смрт за православље“. Лезбејство је овде исказано посредством показне заменице „то“, која подразумева други степен алијенације, дистанцу коју тетка поставља и избегавање именовања сексуалног опредељења путем именице. Премда у бројним песмама постоји јасно тематизована хетеросексуална љубав, она се временом трансформише у хомосексуалну љубав: „мама, чујем шуштање кукуруза / ноћу у овом граду / откако сам схватила // да тога што сам код њега волела / има у једној девојци / само много, много више“ (Petrović 2020: 44). Такву врсту љубави чланови породице доживљавају као болест од које треба излечити и опасност од које треба спасти лирског субјекта. То видимо на примеру стихова песме „Два минута без поезије“: „, сад, којим ћеш ме травама лечити / од топлине њених усана“ (Petrović 2020: 49), али и песми „Сањам оца и ножеве, ножеве, ножеве“ путем стиха „обићи ћеш све врачаре да ме спасеш“ (Petrović 2020: 53). Управо та песма показује се као најзначајнија за обликовање мотива лезбејства. У њој лирски субјекат апострофира оца хипокористиком тата и присећа се њиховог заједничког слушања вести, односно тренутка када се појавила вест да је у Црној Гори донет предлог закона о истополним браковима. Отац лезбејство поима као тренд који је дошао из Америке, тј. са Запада, при чему се ослања на схватање Запада као исувише либералног простора са којег на Балкан долазе различити видови помодарства. Патријархални отац, који је желео сина и уместо њега добио трећу кћер, лезбејским опредељењем кћери добиће снају, делију девојку: „та делија девојка зна да пуца из пушке / можеш у небеса да винеш јабуку //да, тата, имаћеш снају иако немаш сина / видиш колико је домишљат Бог“ (Petrović 2020: 53). Док ова песма функционише као обрачун стварности са породичним хтењима уз јасно прихватање сопственог лезбејства, песма „Брда“ знатно је суптилнија и у њој се даิ приметити порив лирског субјекта да потисне своју лезбејску жељу. Сходно томе, ова кратка песма заснована је на сврси кртичњака у традиционалној култури и на метафори брда: „деда, 
реци ми / шта да закопам у кртичњак / да моји прсти мање хитају / у њена брда“"(Petrović 2020: 52).

\section{4. ФИГУРА МАЈКЕ И ФУНКЦИЈА МАТЕРИНСКОГ}

Када је реч о имплицитно исказаном лезбејству, оно што се чини посебно занимљивим јесте сам наслов збирке. Из наслова Моја мама зна шта се дешава у градовима јасно је да је фигура мајке поетички значајна. Узме ли се у обзир психоаналитичко становиште, долази се до закључка да ово поетско остварење иде у прилог тези да је мајчинство централна тема лезбејске поетике (Sipyinyu Njeng 2007: 28).

Кључан период, у том смислу, јесте прелазни период из преедипалне у едипалну фазу. Тада се и дечаци и девојчице идентификују са мајком, но оно што је карактеристично само за женску децу јесте пролонгирање интимног контакта са мајком, што доводи до већег степена блискости међу припадницама женског пола. У таквој првобитној повезаности са мајком, повезаности са исконским женским, проналази се психоаналитичко утемељење лезбејства - лезбејске везе теже рекреирању емоција и односа карактеристичних за релацију мајка-кћерка (Chodorow 1979: 200).

Управо је мајка једна од централних фигура поетичког система Петровићеве. Из наслова је уочљиво да је мајка неко ко има привилегован положај. Она је та која зна шта се дешава у градовима. Начин на који је описана сигнализира много сложеније значење. У песми која је дала наслов читавој збирци, наилазимо на две битне строфе: „сурутка јој тече под прстима / самоћа се разлистава у стабљике купуса“, односно „разуме језик биља / има одговор на питање земље / али ћути“ (Petrović 2020: 40). Мајка овде има нешто од оног исконског материнског, оног што би била Terra Mater. У том смислу, важна је њена повезаност са земљом и флореалном симболиком која провоцира женски језик ове поезије. Сличну употребу језика биља, повезану с фигуром мајке, проналазимо у спеву Роморанка Ђорђа Марковића Кодера, посвећеном језику „матера наших“. У спеву се тематизује ромор између мајке и умрле кћерке, која у виду птице мајци долази у сан. Ромор подсећа на изворни матерински језик, повезан са женском способношћу рађања, те тако Сава Дамјанов истиче језикотворство, рађање нових речи, као битно својство Кодеровог дела (Дамјанов 2011: 243). У случају Радмиле Петровић, језикотворство препознајемо у карактеристичном креирању и употреби полусложеница. Оне су, као и код Кодера, повезане са сфером флореалног. Дакле, поред полусложеница које се 
односе на сферу родног, појављују се, примера ради, и полусложенице љутић-девојка, девојка-хајдучка трава и реченице-бриљани.

Управо тај језик карактеристичан је за комуникацију мајке и кћерке у поезији Радмиле Петровић, што се најбоље препознаје у песми „Језик биља“: „да ли да им откријемо, мама? / језик биља / нема везе с тим одакле сте // језиком биља говоре мајка и ћерка / кад не причају довољно“ (Petrović 2020: 57). За Јулију Кристеву фигура мајке има пресимболичку функцију (Widawsky 2014: 61), односно мајка се везује за поредак пре речи и знакова, што одговара времену матријархата. У складу с том пресимболичком функцијом јесте и мотив ћутања мајке присутан у поезији Петровићеве. Занимљиво је споменути и песму „Четири пољупца да спасемо свет“, која се завршава стиховима „одвела бих га у три / пичке материне и тамо љубила“ (Petrović 2020: 23), где је повратак изворном материнском присутан путем псовке.

\section{5. ЗАКљУЧАК}

Аутори рада бавили су се родним аспектом песничке збирке Moja мама зна шта се дешава у градовима, који се показује као изузетно значајан за целокупни песнички опус Радмиле Петровић. Конституише се путем језичких иновација отелотворених у бројним полусложеницама, од којих се као најбитнија показује полусложеница шмекер-девојка. Реч шиекер-девојка може се схватити као синегдоха родног идентитета лирског субјекта. Све остале феминине и маскулине родне улоге граде се испољавањем односа према традицији, патријархату, моди и шминкању, али и путем теме лезбејства, коју су аутори рада сагледали, с једне стране, као политички чин, односно, с друге стране, као психоаналитички.

Појава збирке Моја мама зна шта се дешава у градовима Радмиле Петровић може се схватити као својеврстан књижевни догађај, који је значајно утицао на статус женске савремене српске поезије на почетку треће деценије 21. века. Рецепција читалачке публике поставила је младу песникињу у жижу јавности и препознала је њену поезију као нешто ново, превратничко и провокативно. Управо због тога аутори рада одлучили су да је књижевнотеоријски истраже, што је суштински део шире замисли аутора да популаризују озбиљно и подробно књижевно-теоријско истраживање поезије млађе генерације савремених српских песника 21. века како се на плану историје књижевности не би каскало. 


\section{ЛИТЕРАТУРА}

Бодлер, Шарл. 2013. Сликар модерног живота. Београд: Службени гласник. Buttler, Judith. 1990. Gender trouble: Feminism and the subversion of identity. London: Routledge.

Vojvodić, Dejan. 2020. „Volim da se poigravam s onim s čime se ne bi smelo igrati“ (razgovor sa Radmilom Petrović). https://www.rts.rs/ page/magazine/sr/kulturno/story/3158/intervju/4018253/radmila-petrovicpoezija-intervju-rts.html (21.07.2021).

Vulf, Virdžinija. 1964. Gospođa Dalovej. Beograd: Rad.

Дамјанов, Сава. 2011. Велики код: Ђорђе Марковић Кодер. Београд: Службени гласник.

Negrin, Llewellyn. 2000. "Cosmetics and the female body: A critical appraisal of poststructuralist theories of masquerade". European Journal of Cultural Studies 3 (1): 83-101.

Петровић, Радмила. 2015. Мирис земље. Прибој: Дом културе „Пиво Караматијевић“.

Petrović, Radmila. 2020. Moja mama zna šta se dešava u gradovima. Beograd: PPM Enklava.

Ransijer, Žak. 2008. Politika književnosti. Novi Sad: Adresa.

Sipyinyu Njeng, Eric. 2007. "Lesbian poetics and the poetry of Audre Lorde". English Academy Review 24 (1): 23-36.

Chodorow, Nancy. 1979. The Reproduction of Mothering: Psychoanalysis and the Sociology of Gender. Berkeley, CA: University of California Press.

Widawsky, Rachel. 2014. "Julia Kristeva's psychoanalytic work". Journal of the American Psychoanalytic Society 62 (1): 61-67. 
Jovana G. Todorović

Sara Ž. Matin

THE REPRESENTATION OF GENDER IN POEM COLLECTION MOJA MAMA ZNA ŠTA SE DEŠAVA U GRADOVIMA BY RADMILA PETROVIĆ

Summary

In this paper, the poem collection "Moja mama zna šta se dešava u gradovima" (My Mom Knows What's Happening in Cities) by young poetess Radmila Petrović is being researched through analysing elements which shape gender identity and roles of lyrical subject. The third poem collection by Radmila Petrović was in the center of attention of Serbian readership at the beginning of the third decade of the 21 st century because it appeared as innovative in terms of perspective, themes and motifs. There is an important difference between this poem collection and the previous two collections, "Miris zemlje" (The Scent of Earth) and "Celulozni rokenrol" (Cellulose Rock'n'roll). It can be found in thematization of the issue of gender and sex, determined by the context of the village-city opposition. The concept of gender and sex, as the basic denominators by which we can define the sexual identity of a lyrical subject, are connected with the attitude towards tradition, patriarchy, fashion, make-up, but also politics. As such, they prove to be some of the basic concepts for understanding the poetic world that Radmila Petrović builds in this collection. Therefor, three central segments of the paper examine the motif of cosmetics, the motif of lesbianism and the role of the mother figure. The main aim of the paper is to offer a contribution to the scientific study of the poetry of the younger generation of Serbian 21 st century poets.

Key words: contemporary poetry, lesbianism, motif of cosmetics, patriarchy, mother figure 